\title{
THE STUDY ON HUMAN RESOURCE PRACTICES AND AMO MODEL AND ITS IMPACT ON EMPLOYEE COMMITMENT AMONG GEN Y SMES EMPLOYEES IN SELANGOR, MALAYSIA
}

\author{
Norzanah Mat Nor \\ Arshad Ayub Graduate Business School, Universiti Teknologi Mara (UiTM) Shah Alam \\ Elaina Rose Johar* \\ Arshad Ayub Graduate Business School, Universiti Teknologi Mara (UiTM) Shah Alam
}

Siti Murni Mat Khairi

Faculty of Management, PICOMS International University College

\begin{abstract}
Researchers and practitioners have been very enthusiastic and spend the most determinations to study all possible means in order to grab the most advantage from their human resources (HR) especially the Gen Y employees. These employees are pertinent to the part of organisation's strategic business plan and contribute to the organisation's performance as well as sustainable competitive advantage. Hence, employee commitment remains a key challenge especially in small and medium enterprises (SMEs) in Malaysia. The purpose of this paper is to investigate the relationship of compensation, training, employee involvement as well as the ability, motivation and opportunity (AMO) model towards employee commitment. The study also seeks to provide the theory-based empirical evidence that the role of AMO model as a mediator in achieving the commitment of employees and used Social Exchange Theory (SET) in order to explain the theoretical rationale of the study model. A total of $168 \mathrm{Gen}$ Y employees representing SMEs service sectors in Selangor, Malaysia participated in this study. Partial Least Square-Structural Equation Modelling (PLS-SEM) was utilised in order to explain the relationship among HR practices towards employee commitment as well as AMO model as a mediator. A key finding that emerged from the analysis showed that only training has direct relationship toward the employee commitment and AMO model plays an important role in gaining employee commitment as it mediates the relationship of employee involvement. However, compensation has no effect in any relationship. Particularly, this study has helped to place the human resource practices, AMO model and employee commitment in the SET by giving a new perspective theoretically that the correct approach of gaining commitment of employees by providing the appropriate practices that employee will reciprocate in return. Also, it showed that Gen Y employees are seeking more involvement than compensation in order to commit themselves. SMEs should involve employees in their daily activities or any decision-making and offers other recognition programs, as money and remuneration are no longer a motivational urge for employees to become committed. Moreover, the findings could therefore serve as a turning point for SMEs to start concentrating and provide more job-related training so that employees can upgrade their skills particularly in this Industrial 4.0 era, where everything changes greatly in the way they deal with others.
\end{abstract}

Keywords: human resource practices, AMO model, employee commitment, SMEs, Gen Y, millennial

\footnotetext{
- Corresponding author: Elaina Rose Johar, Arshad Ayub Graduate Business School, Universiti Teknologi Mara, Aras 3, Kompleks Al-Farabi 40450 Shah Alam, Selangor, Malaysia; Tel: 03-55444698; E-mail: elainarose.johar@gmail.com
} 


\section{INTRODUCTION}

Notably, in most countries around the world, SMEs represent the pillar of the local economies. In Malaysia, SMEs contribute to one-third of the economy besides being a key driver of Malaysia's economic transformation processes that have contributed to a remarkable effort in promoting growth, employment and income. As such, SMEs accounted for $98.5 \%$ of all business community, contributed to $37.1 \%$ of real gross domestic product and $66.0 \%$ contribution to overall employment (National SME Development Council, 2017). The SME Master Plan has identified several key challenges that weakened the performance of SMEs predominantly in the human capital area, namely workforce lacking job readiness, low utilisation of existing training programs and noncompetitive rewards and benefits. These challenges specifically in human resources management (HRM) have led to the lack of employee commitment due to frequent job switching of the SME employees (National SME Development Council, 2012). Moreover, issues of job hopping are becoming critical in Malaysia as the recent employer brand research by (Randstad, 2019) reported that 21 percent of Malaysian-based employees changed jobs in 2018, 38 percent of respondents plan to change employers in 2019 and also stated that job hopping now has more to do with Millenials and Gen-Zs. Likewise, Chen (2019) also indicated that Millennial in Malaysia are currently dominating a large number of working movements as they comprises 50 per cent of the workforce in 2020 and expected to increase to 75 per cent by the year 2025 . On the other hand, the study by Ganesan et al. (2017) have found out that pay and benefits, training, leadership style, organisational culture and job satisfaction had significant relationship with organisational commitment among Gen Y SMEs employees in Malaysia. Additionally, the chances that employees will remain committed to the organisation rely mainly on their level of productivity and the organisation's commitment to support them (Lee \& Chen, 2013; Osa \& Amos, 2014).

In examining the relationship between human resource practices and employee commitment, many scholars in the past believed that there exists an intervening mechanism that link the HRperformance relationship. HR expert such as Guest (1997; 2011) has suggested that there exist an intervening mechanism in the relationship between HR practices and performance which among others are AMO model (ability, motivation, opportunity). If the AMO model is well understood, the organisation will have a good understanding of the problems related to HR practices, which could also help SMEs to manage its employees and increase their level of commitment. Indeed, Almutawa et al. (2016) suggested that AMO should be used as a mediating variable that links HRM systems and affective commitment of employees. The results show that HR practices have an important and direct influence on the AMO of employees and that the AMO model has partially mediated the relationship between HRM and affective commitment. Similarly, employees are always looking at what the organisation offers in terms of HR practices and the reciprocal act symbolising the core of SET is portrayed by employees suggesting that employees have to react with positive attitudes and behavior and the theory of social exchange emphasises the relationship between employment and mutual exchange more specifically (Latorre et al., 2016). Moreover, social exchange theorists have also suggested that employees are likely to exchange their commitment to employer support, like sound HR practices such as good compensation, appropriate 
training to improve skills and abilities and opportunities for employees to participate as proposed in this study. Based on the previous research concerns, this study aims to examine the application of HR practices to gain employee commitment with AMO model as mediator in Malaysian SMEs as there are still dearth of research that looks into AMO model as intervening variable in the HRperformance relationship especially in Malaysian context. Next, this paper proceeds with literature review, research framework, research methodology, data analysis and discussion of the results.

\section{LITERATURE REVIEW}

\subsection{Employee Commitment}

Commitment is a psychological state that characterises the employee's relationship with the organisation, and has implications for the decision to continue or discontinue membership in the organisation (Meyer \& Allen, 1991). It is further conceptualised as referred to an effective, continuance and normative commitment. It has been reported that, when employees noticed that the organisation involved in the development of their skills and abilities, welfare concerns by compensating them with tolerable compensation and showing confidence in them by designing the work that enables them to participate, the sense of responsibility created in them will be reciprocated with a high level of affective commitment (Almutawa et al., 2016). In addition, the importance of HR practices have improved employee commitment in India (Mahal, 2012). Alternatively, the findings showed that organisational commitment has a major impact on HR practices and further asserted that the pillar of the modern HRM philosophy is organisational commitment. Nevertheless, both Almutawa et al. (2016) and Mahal (2012) studies were only focused on affective commitment alone; therefore, two other types of employee commitment are required because it is important not only to maintain the emotional attachment of the employees, but also to maintain the employee's obligation as well as to cover the costs of leaving the workforce. (Hashim, 2010) had in fact, started a study on HRM-based practice in Malaysia based on the Islamic perspective and the relationship with organisation commitment. The findings showed that Islamic HRM practices had an impact on the organisational commitment of employees in Malaysia. However, the analysis would be more meaningful if an analysis result of each construct was included rather than computing all HRM practices as a single factor, i.e., the HRM Islamic approach.

\subsection{Human Resource Practices}

Scholars and practitioners had acknowledged the role of HRM in enabling the company to remain competitive. Noe et al. (2010) defined HRM as a philosophy, policy, system and practice of employee behaviour, attitudes and performance. It was only recently that the organisation realised the possible role of HRM in increasing organisational performance, which had previously overlooked the goal of HRM in contributing to organisational success (Zakaria et al., 2011). There are, in fact, certain practices that form the basis of the diverse practices proposed by many of the previous HRM scholars and they had agreed that there is no agreement on what HRM practices should include. In particular, the number of practices shall be maintained as long as the organisation is aware of the needs and requirements of employees in order to assist in the achievement of the specific organizational objective. For the purpose of this study, compensation, training and employee involvement were chosen out of seven practices suggested by (Guest, 1997). 
Selection of the practices for this study was based on the preliminary interview with some of SMEs on the appropriate HR practices as well as its recurrence in the literature reviewed. Compensation was chosen because it was deemed as a source of motivation to increase productivity and training could possibly increase skills and ability of the employees. On the other hand, increased commitment and improved autonomy space will be achieved as a result of the ownership and responsibility of employee's involvement. Moreover, it is a good step to launch an investigation into the role of compensation, training and employee involvement especially in the current working environment inhabited by the new generation cohort. The following is a list of the practices and definitions in relation to this study.

\subsubsection{Compensation and Employee Commitment}

Ideally, reward or compensation is rather a basis for motivation and control but also an incentive for higher productivity (Poole, 1997). Hence, compensation is any kind of payment, monetary reward, non-monetary, and a decision a firm makes regarding payment of its workers, including pay levels, pay mixes, pay structures, and pay raises (Cardon \& Stevens, 2004; Mulolli, Islami, \& Skenderi, 2015). Subsequently, whilst Abdullah et al. (2010) found out that financial constraint is the main limitation for SMEs to offer attractive salary packages, there are other past studies that revealed compensation has a significant positive effect on employee commitment. Coetzee et al. (2014) had found that affective and normative commitment was significantly and positively predicted by rewards and remuneration in their study of 284 professionally qualified South African engineers. This relationship shows that it is rather important for fairness and remuneration to match job roles and responsibilities. Moreover, the results of this study showed that young employees, such as engineers aged 36 years and below, can become committed if the organisation effectively manages HR practices. Mabaso and Dlamini (2018) on their study of the higher education sectors in South Africa confirmed that total rewards that include compensation have a strong relationship with employee commitment. It showed that with proper design of total rewards and recognition, it will further increase commitment among academicians. Moreover, if employees were not satisfied with salaries and fringe benefits, they will have no choice other than to look for alternative organisations that will be providing better salaries and benefits. Therefore, it is hypothesised that:

\section{$\mathbf{H}_{1}$ : Compensation has a significant direct relationship with employee commitment.}

\subsubsection{Training and Employee Commitment}

Training denotes to the methods used to give new or present employees the skills, knowledge, behaviors and other abilities they need to perform their jobs, modify individuals' skills or attitudes as well as to help in the development of positive dispositions towards growth and change as ratified by individuals, groups and teams (DeNisi \& Griffin, 2001; Herold \& Fedor, 2003; Lyons, 2009). Likewise, it refers to a learning opportunities provided by the employer in a structured manner with the aim to achieve development in employees' knowledge, skills and attitudes (Bashir \& Long, 2015). Education and training had a significant positive impact on the commitment of employees based on the study of financial holding companies in Taiwan (Lin et al., 2012). According to the study, when the training system of the organization is more comprehensive, employees will retain in the organisation and develop emotional attachment. This is due to the fact that employees can develop new learning and skills through training and also the ability to solve problems, able to do job independently and less worry. Separately, a study by Ihionkhan and Aigbomian (2014) of the 
major manufacturing organisations in Nigeria showed that the greatest correlation between HRM activities and organisational commitment was the training and development dimension. The organisation provides appropriate training and development, leading to greater efficiency, effectiveness and overall productivity. Training in manufacturing organisations is vital, as employees need to have the knowledge and appropriate skills to operate machinery and computer systems on a daily operation. Hence, it is hypothesised that:

\section{$\mathbf{H}_{2}$ : Training has a significant direct relationship with employee commitment.}

\subsubsection{Employee Involvement and Employee Commitment}

Employee involvement involves human capacity, responsibility and ownership and it is important to organisation as it will ensure those vision and values are achieved (Amah \& Ahiauzu, 2013). Subsequently, better commitment and improved space for autonomy will be attained as a result of ownership and responsibility. An organisation that concerns about employee commitment should instil policies and practices that can win the heart and mind of the employees such as information sharing, decision-making, and empowerment (Zopiatis et al., 2014). Chelliah et al. (2015) in a study of private Malaysian organisations in Penang found that participation in job resulted in a positive relationship with affective, continuance and normative commitment. Job involvement is likely to be influenced by employer involvement, worker views of job significance, employee clarification of role requirements, career advancement prospects, frequent input and discussion with supervisors, performance of working relationships with colleagues, superiors and subordinates, impressions of the organisation's culture and values, effective internal employee communications and rewards to engage them. The positive and significant results presuppose that their efforts must be consistent with their values in order to get employees involved, thus enabling organisations to have meaningful understanding. Subsequently, recent study by Johar et al. (2019) on HR practices which includes employee involvement on normative commitment specifically shows that employee commitment has a significant positive relationship with normative commitment. This study also includes motivation as a mediating variable on the relationship. The findings clearly show that when employees were given the empowerment and chance to involve in the decision-making, it will help to boost the motivation, sense of responsibility and feeling of satisfaction when their voices were heard. Thus, it is hypothesised that:

\section{H3: Employee involvement has a significant direct relationship with employee commitment.}

\subsection{AMO Model and Employee Commitment}

Appelbaum et al. (2000) had introduced the AMO framework, consisted of the three elements that improved employee performance, i.e. individual ability (A), motivation (M), and the opportunity to participate (O). Boxall and Purcell (2011) observed that, according to this model, people perform well when they can do the job (abilities), they will do the job (motivation) and their work environment provides the necessary support and avenues for expression (opportunity). In the same vein, this model contains three systems that outline individual characteristics in confirming that employees have the right skills, motivating employees to develop discretionary behaviours and empowering them towards organisational outcomes (Tabiu et al., 2016). Guest (1997; 2011) proposed to use AMO model to serve as a mediating mechanism through which HRM affect performance and limited empirical efforts were found to explore the mediating effect of the AMO 
model in the HRM-performance relationship. Indeed (Almutawa et al., 2016) suggested that AMO should be used as a mediating variable that links HRM systems and affective commitment of employees. The results showed that HRM had an important and direct influence on the AMO of employees and that the AMO model had partially mediated the relationship between HRM and affective commitment. The recent study by Nor and Abdullah (2020) used AMO model as underlying of high-performance work practices (HPWP) conceptualization on the relationship with organisational performance and job embeddedness as mediator. This study focused on the millennial employees in one of the government agencies in Kuala Lumpur, Malaysia. The results revealed that the AMO enhancing practices are important in the current organisational setting where the workforce is dominated by the millennial. This finding could help organisation to gauge the performance of employees by providing the right human resource practices. However, this study could have been done and improved with large number of respondents and involve private sector as well. Thus, it is hypothesised that:

H4: AMO model has a significant direct relationship with employee commitment.

H5: Compensation has a significant relationship with AMO model.

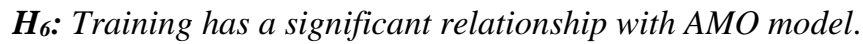

H7: Employee involvement has a significant relationship with AMO model.

$\boldsymbol{H}_{8}:$ AMO model mediates the relationship between compensation and employee commitment.

H9: AMO model mediates the relationship between training and employee commitment.

H10:AMO model mediates the relationship between employee involvement and employee commitment.

\subsection{Social Exchange Theory (SET)}

The research framework (Figure 1) shows the model and literature on employee commitment, compensation, training employee involvement, and the AMO model using the SET as the most appropriate framework for this study. Blau (1964) introduces SET as the best analytical tool for integrating perceptions and attitudes and linking them to performance. Similarly, as human resource practices indicate to employees what the organisation has to offer, employees will at the same time demonstrates an act of reciprocity that is at the heart of SET, which means that employees will feel obliged to react with positive attitudes and behaviour. Subsequently, when the organisations meet the needs of employees and meet their expectations at the workplace, they will feel appreciative and a factor called the reciprocal norm comes into play when they gain appreciation for their work; these employees will reciprocate with a sense of duty and respond with continued high performance Wayne et al. (2002) and as per the SET, a higher level of involvement and commitment (Saks, 2006).

Individuals may choose to leave existing relationships or social exchanges if the relationship outcomes are lower than expected. In other words, it means that employees will leave the organisation or will not committed unless they see any benefits or reciprocity of their actions in 
the relationship with the employer. In addition, SET also offers rewards that will motivate individuals to engage in social exchanges. As such, if the employer compensates employees with something that is equal to or more than what they qualify for, the more likely employees will make a commitment in return for the reward. SET is the theoretical foundation for explaining why employees choose to remain and stay with their work and organisation as well as to feel oblige to pay back their organisation's resources and remain with the organisation when these resources were received from their organisation (Saks, 2006).

Moreover, humans were viewed as rationally choosing more beneficial social behaviors as a result of rational reviews of all available information. Because all behavior is costly in that it requires an expenditure of energy on the part of the actor, only those behaviors that were rewarded or that produced the least cost tend to be repeated. Thus, social exchanges take on an air of consistency in that patterns of rewards often remains stable in social relationships (Chibucos et al., 2004). Hence, studies have found that high levels of employee involvement and job security contributed to increased employee commitment (Gallie et al., 2001; Guest et al., 2000; Whitener, 2001) which, consistent with social exchange theories, that employees used 'currency' of work-related behaviors to reciprocate management behavior (Aryee et al., 2002).

\subsection{Research Framework}

A research framework (Figure 1) demonstrates the model and literature relating to employee commitment, compensation, training, employee involvement, and AMO model with the use of SET as the most suitable framework in this study. As been discussed in the previous section, Blau (1964) introduces SET as the best analytical tool to integrate perceptions and attitudes and relate them to performance. Likewise, as human resource practices indicate employees on what the organisation has to offer, the employees at the same time will also show the act of reciprocity that represents the heart of SET, which suggests that employees will feel obliged to react with positive attitudes and behaviour.

Figure 1: Research framework

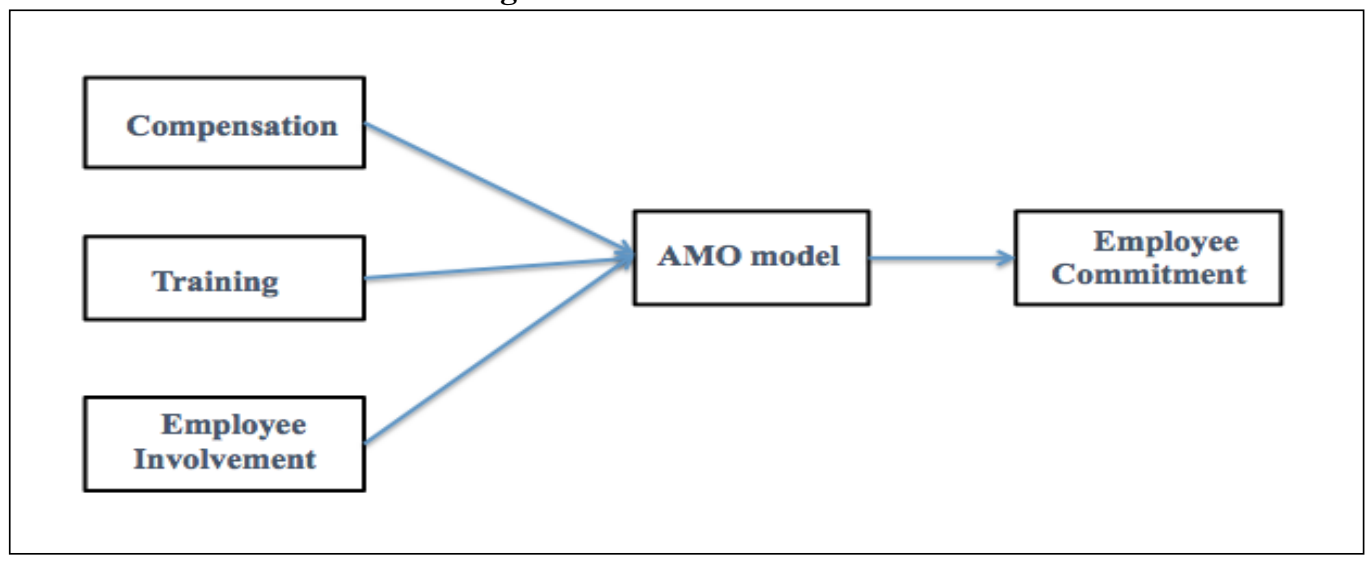




\section{METHODOLOGY}

In general, SMEs are the largest number of establishments in many countries worldwide. Without exception, these SMEs accounted for 98.5 percent of the total number of establishments in Malaysia (National SME Development Council, 2017). According to the Economic Census 2016, Department of Statistics Malaysia, the service industry represents 89.2 percent of the total number of SMEs in Malaysia and Selangor has the highest concentration of SMEs in Malaysia (19.8\%). Despite being the largest sector, the service sector was chosen because previous studies have shown that research into service sector firms is scarce (Jones et al., 2010; Hooi \& Ngui, 2014; Shin \& Konrad, 2014).

The sampling frame for this research study consisted of SMEs in Selangor and used the list of SMEs that received and won the Enterprise 50 (E50) Award from 1998 to 2017 from the SME Corporation Malaysia. The reason being that the award honours the top 50 SMEs in the country annually in recognition of their achievements in financial capabilities, operations and management skills. The winners have therefore established their management not only as successful enterprises, but also as productive national assets and global players (SME Corporation Malaysia, 2017). Thus, the list consisted of 100 service sector SMEs in Selangor, Malaysia and, as a result, there were 3000 employees in total, each of whom has at least 30 employees based on the definition of SMEs (National SME Development Council, 2017).

However, the respondents for this research study consisted of Gen Y employees of service sector SMEs in Selangor, Malaysia. Gen Y or millennial employees are those people who were born from 1981 to 2000 (Brown et al., 2015). There is no doubt that each type of generation contributes to the different characteristics as the economic and social environment were varied at that specific time. Additionally, PricewaterhouseCoopers (PwC) report stated that by 2020 more than 50 percent of the workforce will be the millennial or Gen Y (PricewaterhouseCoopers, 2011; Queiri et al., 2014). It is therefore crucial for organisations to develop a strategy that can attract and retain millennial as well as preparing their young talents for future leadership roles.

The respondent pool was obtained through the questionnaire survey and 168 usable data were collected in the research study. G*Power was used to estimate the minimum sample size of the research study and to carry out an analysis of the current framework with three predictors requiring a minimum sample size of 119 , which would produce a power of 0.95 for the medium effect size model (Hair et al., 2013). Nevertheless, the sample size was increased to 300 in order to reduce the risk of non-response bias that could result from the refusal of the sample members to respond, unable to respond or inaccessible to the researcher (Merkle, 2008; Williams, 1978; Yu \& Cooper, 1983). Thus, the sample size of 300 divided by 30 employees in each SMEs leads to 10 SMEs as a sample of the available sampling framework. Alternatively, this study decided to increase the number of SMEs to 50 and all these SMEs were chosen using a systematic sampling technique. This 50 number of SMEs were used as the actual sample size for sampling. Saunders et al. (2009) suggested that systematic sampling involves the selection of samples from the sampling frame at regular intervals and the application of the sampling fraction formula. The sampling fraction obtained for this study is $50 / 100$ or $1 / 2$, which is one in every second case selected from the sampling frame. The selected SMEs were then contacted to obtain permission to contact the targeted respondents via email. 
Additionally, from the list of E50 winners SMEs that have been contacted, more than half of the total respondents were female (63\%) and among the Malays (83\%). Furthermore, majority of the Gen Y employees hold an executive position in the company (57\%), most of them with two to five years of experiences (55\%) and earned monthly income between RM1000 - RM3000 (59\%). The measurement items used for the questionnaire were already identified from previous literature. The items for compensation were adapted from Geringer et al. (2002); Vandenberg et al. (1999); training from Vandenberg et al. (1999); Wayne et al., 1997) and employee involvement from Adham (2011). Next, the items for the AMO model were adapted from Guay et al. (2000); Rizzo et al. (1970); Schyns \& Collani (2002). The items for employee commitment were adapted from Meyer and Allen (1991) to measure the employee's commitment towards the organisation. The questionnaires were measured using a 7-point Likert-type scale, ranging from 1 (strongly disagree) to 7 (strongly agree).

\section{RESULTS AND DISCUSSION}

In this research study, the PLS-SEM approach was used to test the relationship for the model that has been developed. PLS is a second-generation multivariate technique that can simultaneously evaluate the measurement model (the relationship between constructs and their corresponding indicators) and the structural model with the aim of minimising the error variance of the data Hair et al., 2017). PLS bootstrapping method was used to determine the significance level for loadings, weights, and path coefficients. Besides that, the common method variance needs to be assessed because all data was collected through self-reported questionnaires, and both the predictor and criterion variables were gathered from the same source (Podsakoff et al., 2003). Hence, to curb this issue, full collinearity test was done by creating a block in which all the latent variables in the model are included as predictors pointing at one single criterion, a dummy variable (Kock \& Lynn, 2012). Furthermore, this test of collinearity is deemed as more comprehensive and conservative as it allows for the identification of collinearity among all the variables in the model, regardless of where they are located in the model. In fact, different latent variables refer to different constructs, whether they are in the same block on not in a SEM model. In this research, the full collinearity estimates (Table 1) shows that the variance inflation factor (VIF) for all the variables are less than 3.3 as VIFs equal to or greater than 3.3 suggest the existence of collinearity in the context of variance-based SEM. Thus, it confirms that common method bias is not a problem in this research study.

Table 1: Full Collinearity Estimates

\begin{tabular}{cccccc}
\hline \hline & & & Employee & Employee & \\
& AMO & Compensation & Commitment & Involvement & Training \\
\hline VIF & 2.019 & 1.912 & 1.897 & 2.818 & 2.419 \\
\hline \hline
\end{tabular}

Notes: The VIFs shown are for all of the latent variables; a "dummy" latent variable criterion was used. VIFs equal to or greater than 3.3 suggest collinearity.

\subsection{Measurement Model Evaluation}

The first step in assessing the data is to evaluate the measurement model of the research study. The measurement model was evaluated by two types of validity, that is the convergent validity (CV) 
[loading, average variance extracted (AVE), composite reliability (CR)] and discriminant validity (DV) (Hair et al., 2017). CV evaluates whether or not the items represent the same underlying construct and the threshold value are above 0.6 for loadings indicators, above 0.5 for AVE and above 0.7 for CR. However, not all loadings below 0.6 are excluded. The removal only needed if it helps to increase the value of AVE (Hair et al., 2017). As in Table 2, the results of the measurement model exceeded the recommended values; thus, indicating sufficient convergence validity. Correspondingly, AMO model and employee commitment have been conceptualised as a second-order construct. Thus, this study followed the method suggested in the literature in PLS, which is the repeated indicator approach to model the second-order factors in the PLS analysis (Hair et al., 2018).

At the next level, DV indicated the extent to which a construct differs from other constructs within the model. The DV assessment was drawn the from Henseler et al. (2015) heterotrait-monotrait ratio of correlations (HTMT) measure. The results in Table 3 shows that the HTMT values for all approaches yielded similar results that are below the conservative threshold of 0.85 (Franke \& Sarstedt, 2019; Kline, 2016; Voorhees et al., 2016). The bootstrapping procedure was run with 5000 samples. The results show that none of the HTMT confidence intervals includes the value of 1, suggesting that all HTMT values are significantly different from 1.

Table 2: Measurement Model

\begin{tabular}{|c|c|c|c|c|c|}
\hline First-order construct & $\begin{array}{c}\text { Second-order } \\
\text { construct }\end{array}$ & & Factor Loadings & AVE & CR \\
\hline \multirow{3}{*}{$\begin{array}{c}\text { Affective } \\
\text { commitment }\end{array}$} & & $\mathrm{AC} 1$ & 0.861 & 0.73 & 0.89 \\
\hline & & $\mathrm{AC} 2$ & 0.823 & & \\
\hline & & AC5 & 0.845 & & \\
\hline \multirow{6}{*}{$\begin{array}{l}\text { Continuance } \\
\text { commitment }\end{array}$} & & $\mathrm{CC} 1$ & 0.777 & 0.598 & 0.899 \\
\hline & & $\mathrm{CC} 2$ & 0.828 & & \\
\hline & & $\mathrm{CC} 3$ & 0.781 & & \\
\hline & & $\mathrm{CC} 4$ & 0.784 & & \\
\hline & & CC5 & 0.737 & & \\
\hline & & CC6 & 0.723 & & \\
\hline \multirow{6}{*}{$\begin{array}{l}\text { Normative } \\
\text { commitment }\end{array}$} & & NC2 & 0.684 & 0.658 & 0.905 \\
\hline & & $\mathrm{NC} 3$ & 0.821 & & \\
\hline & & $\mathrm{NC} 4$ & 0.859 & & \\
\hline & & NC5 & 0.88 & & \\
\hline & & NC6 & 0.792 & & \\
\hline & $\begin{array}{c}\text { Employee } \\
\text { commitment }\end{array}$ & & & 0.711 & 0.88 \\
\hline \multirow[t]{7}{*}{ Compensation } & & $\mathrm{C} 1$ & 0.864 & 0.601 & 0.912 \\
\hline & & $\mathrm{C} 2$ & 0.87 & & \\
\hline & & $\mathrm{C} 3$ & 0.853 & & \\
\hline & & $\mathrm{C} 4$ & 0.806 & & \\
\hline & & $\mathrm{C} 5$ & 0.738 & & \\
\hline & & C6 & 0.578 & & \\
\hline & & $\mathrm{C} 7$ & 0.666 & & \\
\hline
\end{tabular}




\begin{tabular}{|c|c|c|c|c|}
\hline \multirow[t]{7}{*}{ Training } & T1 & 0.855 & 0.714 & 0.946 \\
\hline & $\mathrm{T} 2$ & 0.779 & & \\
\hline & T3 & 0.83 & & \\
\hline & $\mathrm{T} 4$ & 0.846 & & \\
\hline & T5 & 0.905 & & \\
\hline & T6 & 0.861 & & \\
\hline & $\mathrm{T} 7$ & 0.834 & & \\
\hline \multirow{13}{*}{$\begin{array}{c}\text { Employee } \\
\text { involvement }\end{array}$} & EI1 & 0.577 & 0.507 & 0.929 \\
\hline & EI2 & 0.578 & & \\
\hline & $\mathrm{EI} 3$ & 0.691 & & \\
\hline & EI4 & 0.535 & & \\
\hline & EI5 & 0.553 & & \\
\hline & EI6 & 0.781 & & \\
\hline & EI7 & 0.753 & & \\
\hline & EI8 & 0.8 & & \\
\hline & EI9 & 0.689 & & \\
\hline & EI10 & 0.791 & & \\
\hline & EI11 & 0.834 & & \\
\hline & EI12 & 0.82 & & \\
\hline & EI13 & 0.755 & & \\
\hline \multirow[t]{7}{*}{ Ability } & A1 & 0.57 & 0.647 & 0.927 \\
\hline & $\mathrm{A} 2$ & 0.809 & & \\
\hline & $\mathrm{A} 3$ & 0.83 & & \\
\hline & A4 & 0.836 & & \\
\hline & A5 & 0.868 & & \\
\hline & A6 & 0.859 & & \\
\hline & A7 & 0.818 & & \\
\hline \multirow[t]{5}{*}{ Motivation } & M1 & 0.844 & 0.639 & 0.898 \\
\hline & M2 & 0.738 & & \\
\hline & M4 & 0.745 & & \\
\hline & M5 & 0.839 & & \\
\hline & M7 & 0.805 & & \\
\hline \multirow[t]{6}{*}{ Opportunity } & O1 & 0.612 & 0.525 & 0.845 \\
\hline & $\mathrm{O} 2$ & 0.572 & & \\
\hline & $\mathrm{O} 3$ & 0.801 & & \\
\hline & $\mathrm{O} 4$ & 0.827 & & \\
\hline & O6 & 0.659 & & \\
\hline & & & 0.687 & 0.868 \\
\hline
\end{tabular}

Notes: $\mathrm{AVE}=$ average variance extracted; $\mathrm{CR}=$ composite reliability 
Table 3: Discriminant Validity Assessment Using the HTMT Criterion

\begin{tabular}{|c|c|c|c|c|c|}
\hline & AMO & "Compensation & $\begin{array}{c}\text { Employee } \\
\text { Commitment }\end{array}$ & $\begin{array}{c}\text { Employee } \\
\text { Involvement }\end{array}$ & "Recruitment \\
\hline \multicolumn{6}{|l|}{ AMO } \\
\hline Compensation & $\begin{array}{c}0.501 \\
(0.377 \\
0.606)\end{array}$ & & & & \\
\hline Employee & 0.62 & 0.509 & & & \\
\hline Commitment & $\begin{array}{c}(0.496 \\
0.711)\end{array}$ & $(0.349 ; 0.625)$ & & & \\
\hline Employee & 0.758 & 0.652 & 0.61 & & \\
\hline Involvement & $\begin{array}{c}(0.679 ; \\
0.823)\end{array}$ & $(0.538 ; 0.742)$ & $(0.488 ; 0.7)$ & & \\
\hline Training & $\begin{array}{c}0.567 \\
(0.445 \\
0.676)\end{array}$ & $\begin{array}{c}0.684 \\
(0.574 ; 0.776)\end{array}$ & $\begin{array}{c}0.618 \\
(0.487 ; 0.71)\end{array}$ & $\begin{array}{c}0.73 \\
(0.62 ; 0.828)\end{array}$ & \\
\hline
\end{tabular}

Notes: The values in brackets represent the $95 \%$ bias-corrected and accelerated confidence interval of the HTMT values obtained by running the bootstrapping routine with 5,000 samples in SmartPLS.

\subsection{Structural Equation Modelling - Partial Least Squares}

Assessment of structural model involves examining the model's predictive capabilities and the relationship between the constructs in the path model, which includes assessment of collinearity (variance inflation factor, VIF), assessment of coefficient of determination $\left(\mathrm{R}^{2}\right)$, and the effect size $\left(\mathrm{f}^{2}\right)$ (Hair et al., 2017). The VIF values in Table 4 are clearly below the threshold of 5 (a tolerance value below 0.2 and above 5 indicate a potential collinearity problem) (Hair et al., 2011). This indicates that collinearity among the predictor constructs was not a critical issue in the structural model. Next, Hair et al. (2017) noted that the $\mathrm{R}^{2}$ is a measure of the model's predictive power and is identified as the squared correlation between a specific endogenous construct's (AMO model and employee commitment) actual and predicted value. The rule of thumb for $\mathrm{R}^{2}$ values of 0.75 , 0.50 , or 0.25 can be respectively described as substantial, moderate, or weak (Hair et al., 2011; Henseler et al., 2009). Hence, the $\mathrm{R}^{2}$ values of AMO model (0.488) and employee commitment (0.479) are considered as moderate. In other words, the independent variable in this study accounted for 47.9 per cent of the variance in the employee commitment. Subsequently, $\mathrm{f}^{2}$ is referred to the change of $\mathrm{R}^{2}$ value when a specified exogenous construct (compensation, employee involvement, training) was omitted from the model (Hair et al., 2017). The $\mathrm{f}^{2}$ value of $0.02,0.15$ and 0.35, respectively, represent small, medium, and large effect (Cohen, 1988). Thus, Table 4 illustrates that compensation showed no effect with the value of 0.002 and small effect size of 0.012 on the AMO model and employee commitment respectively, training showed no effect of 0.006 and small effect of 0.071 on the AMO model and employee commitment respectively, while employee involvement showed large effect of 0.352 and small effect of 0.014 on both AMO model and employee commitment respectively. 
Table 4: Coefficient of determination $\left(\mathrm{R}^{2}\right)$, Collinearity Assessment (VIF) and Effect size $\left(\mathrm{f}^{2}\right)$

\begin{tabular}{|c|c|c|c|c|c|}
\hline & \multirow[t]{2}{*}{$\mathrm{R}^{2}$} & \multicolumn{2}{|r|}{ VIF } & \multicolumn{2}{|r|}{$\mathrm{f}^{2}$} \\
\hline & & AMO & Employee Commitment & AMO & Employee Commitment \\
\hline Employee & 0.479 & & & & \\
\hline Commitment & & & & & \\
\hline AMO & 0.488 & - & 1.953 & - & 0.078 \\
\hline Compensation & & 1.877 & 1.88 & 0.002 & 0.012 \\
\hline Employee & & 2.074 & 2.803 & 0.352 & 0.014 \\
\hline Involvement & & & & & \\
\hline Training & & 2.24 & 2.254 & 0.006 & 0.071 \\
\hline
\end{tabular}

\subsection{Findings of the Structural Model Path Coefficient}

To estimate the structural model, a bootstrapping procedure with 5000 resamples was run to generate the t-values and p-values. First, this study looked at the factors that link to employee commitment, which is compensation, training, employee involvement, and AMO model. The AMO model and training have a direct relationship with employee commitment (Table 5). This is because the $\mathrm{t}$ value is higher than the critical value, 1.645 at $5 \%$ significance level, the $\mathrm{p}$-value of this relationship is lower than the significance level of 0.05 , and the confidence interval for the relationship also shows a similar result, which does not include zero. Thus, the hypotheses $\mathbf{H}_{2}$ and $\mathbf{H}_{4}$ are supported. On the other hand, compensation and employee involvement show insignificant direct relationship towards employee commitment. Hence, the hypothesis $\mathbf{H}_{\mathbf{1}}$ and $\mathbf{H}_{\mathbf{3}}$ are not supported. Next, the research study observed the predictors of AMO model as in Table 6, which are compensation, training and employee involvement. Employee involvement has significant positive relationship with the AMO model. However, compensation and training show insignificant direct relationship towards the AMO model. The results indicate that the hypothesis $\mathbf{H}_{7}$ is supported, while $\mathbf{H}_{5}$ and $\mathbf{H}_{6}$ are not supported.

\subsection{Findings of the Mediation Effect}

Table 7 shows that there exists mediation effect of the AMO model between employee involvement and employee commitment. The mediation effect is classified as full mediation, which is indirect. Accordingly, the indirect effect of employee involvement shows that the t value of employee involvement is higher than the critical value $(\mathrm{t}=1.96)$ and the direct effect value is not significant. Hence, hypothesis $\mathbf{H}_{10}$ is accepted as full mediation. The total effect of employee involvement towards employee commitment is 0.314 for both indirect effects and direct effects as shown in Table 7. For hypothesis $\mathbf{H}_{9}$, the indirect effect shows that the $t$ value of training is below the critical value, but for the direct effect value it is significant. Therefore, hypothesis $\mathbf{H} \mathbf{9}$ has no effect on mediation. Furthermore, for hypothesis $\mathbf{H}_{8}$, both the indirect and direct effects show that the t value of compensation is below the critical value and thus concludes as no effect for the relationship. 
Table 5: Significance Testing Results of the Structural Model Path Coefficients on the employee commitment

\begin{tabular}{cccccc}
\hline \hline & $\begin{array}{c}\text { Path } \\
\text { Coefficients }\end{array}$ & t values & p values & $\begin{array}{c}\text { 95\% Confidence } \\
\text { Interval }\end{array}$ & $\begin{array}{c}\text { Significanc } \\
\mathbf{e}(\mathbf{p}<\mathbf{0 . 0 5})\end{array}$ \\
\hline AMO model $\rightarrow$ & & & & & \\
EC & 0.281 & 3.019 & 0.003 & {$[0.107 ; 0.474]$} & Yes \\
C -> EC & 0.108 & 1.095 & 0.273 & {$[-0.096 ; 0.288]$} & No \\
T -> EC & 0.289 & 3.038 & 0.002 & {$[0.105 ; 0.474]$} & Yes \\
EI -> EC & 0.142 & 1.508 & 0.132 & {$[-0.045 ; 0.328]$} & No \\
\hline \hline
\end{tabular}

Notes: $\mathrm{C}$ is compensation, $\mathrm{T}$ is training, EI is employee involvement and EC is employee commitment.

Table 6: Significance Testing Result of Structural Model Path Coefficient on the AMO model

\begin{tabular}{cccccc} 
& $\begin{array}{c}\text { Path } \\
\text { Coefficients }\end{array}$ & t values & p values & $\begin{array}{c}\mathbf{9 5 \%} \\
\text { Confidence } \\
\text { Intervals }\end{array}$ & $\begin{array}{c}\text { Significance } \\
(\mathbf{p}<\mathbf{0 . 0 5})\end{array}$ \\
\hline C $>$ AMO model & 0.041 & 0.5 & 0.617 & {$[-0.129 ; 0.198]$} & No \\
T $>$ AMO model & 0.084 & 0.892 & 0.005 & {$[-0.101 ; 0.271]$} & No \\
EI $\rightarrow$ AMO model & 0.611 & 8.42 & 0.000 & {$[0.47,0.755]$} & Yes \\
\hline \hline
\end{tabular}

Notes: $\mathrm{C}$ is compensation, $\mathrm{T}$ is training and $\mathrm{EI}$ is employee involvement.

Table 7: Significance Analyses of Direct, Indirect Effect and Total Effect

\begin{tabular}{|c|c|c|c|c|c|c|c|c|c|c|}
\hline & $\begin{array}{l}\text { Direct } \\
\text { effect }\end{array}$ & $\begin{array}{c}95 \% \\
\text { Confidence } \\
\text { Interval of } \\
\text { the Indirect } \\
\text { Effect }\end{array}$ & $\begin{array}{c}\mathrm{t} \\
\text { values }\end{array}$ & Sig & $\begin{array}{c}\text { Indirect } \\
\text { effect }\end{array}$ & $\begin{array}{c}95 \% \\
\text { Confidence } \\
\text { Interval of } \\
\text { the Indirect } \\
\text { Effect } \\
\end{array}$ & $\begin{array}{c}\mathrm{t} \\
\text { values }\end{array}$ & Sig & $\begin{array}{l}\text { Total } \\
\text { effect }\end{array}$ & $\begin{array}{c}\text { Mediation } \\
\text { type }\end{array}$ \\
\hline $\begin{array}{l}\mathrm{C}-> \\
\mathrm{EC}\end{array}$ & 0.108 & $\begin{array}{c}-0.096 \\
0.288]\end{array}$ & 1.095 & No & 0.012 & $\begin{array}{c}{[-0.035 ;} \\
0.059]\end{array}$ & 0.502 & No & 0.12 & No Effect \\
\hline $\begin{array}{l}\mathrm{T}-> \\
\mathrm{EC}\end{array}$ & 0.289 & $\begin{array}{c}{[0.105 ;} \\
0.474]\end{array}$ & 3.038 & Yes & 0.024 & $\begin{array}{l}{[-0.02 ;} \\
0.095]\end{array}$ & 0.84 & No & 0.313 & $\begin{array}{c}\text { Direct } \\
\text { only }\end{array}$ \\
\hline $\begin{array}{c}\text { EI-> } \\
\text { EC }\end{array}$ & 0.142 & $\begin{array}{c}{[-0.045 ;} \\
0.328]\end{array}$ & 1.508 & No & 0.172 & $\begin{array}{c}{[0.061 ;} \\
0.318]\end{array}$ & 2.686 & Yes & 0.314 & $\begin{array}{c}\text { Indirect } \\
\text { Only } \\
\text { (Full } \\
\text { Mediation) }\end{array}$ \\
\hline
\end{tabular}

Notes: C is compensation, T is training, EI is employee involvement, EC is employee commitment. Sig is significance at $(\mathrm{p}<0.05)$

The purpose of this study is to investigate the relationship between HR practices (compensation, training and employee involvement) towards employee commitment of the Gen Y employees of SMEs in Selangor, Malaysia and to determine the role of AMO model as the intervening variable between the relationships. The findings showed that training and AMO model had a significant direct relationship with employee commitment. Notably, Gen Y employees were equipped with proper and adequate training that can uphold and increase their job skills, which eventually make them become more committed. In addition, the findings were consistent with Coetzee et al. (2014), who suggested that training helps to improve the knowledge and skills of employees. It has been an important practice to increase the affective and normative commitment of professional qualified engineers in South Africa. In addition, training is seen as a way of investing human capital, leading 
to a change in the attitudes of employees, which inevitably improves organisational commitment (Ling et al., 2014). Correspondingly, when employees received training from the organisation, they were aware of the value added or extra knowledge they gained through the training. The training provided not only offers a better understanding but also makes them feel psychologically motivated and glad to do their job more effectively and more likely to stay in the organisation. This feeling of reciprocity will lead to the commitment of employees within the organisation. Moreover, AMO model also yields the same significant result with employee commitment as previous studies (Almutawa et al., 2016; Bos-Nehles et al., 2013). When employees especially the Gen Y, perceived that the organisation is interested in improving their skills and abilities, cares about their well being and designing the job in ways that enable them to effectively participate, they will show the act of reciprocity through commitment. Nonetheless, compensation and employee involvement have no significant relationship with employee commitment. This finding contradicts with previous studies that found significant relationship between compensation (Hassan \& Mahmood, 2016; Hashim et al., 2016) and employee involvement (Adham, 2011; Chelliah et al., 2015) with employee commitment. Remarkably, Gen Y employees did not rely on the only source of income which is salary but rather find other alternatives to earn extra and passive income elsewhere. Additionally, Gen Y employees' involvement did not increase their commitment. This might due to the failure of the organisation to understand the needs and wants of the new generation (Gen Y) that coming into the workforce. This new cohort of employees probably needs more empowerment and opportunity to unleash their potential.

Secondly, the results indicated that only employee involvement has a significant positive relationship with the AMO model. Obviously, when organisation provides supporting working environment and actively involved employees in management activities, employees were keen to unleash their skills and capabilities as well. Thus, employees will perform well when they can do the job (abilities), they will do the job (motivation) and their work environment provides the necessary support and avenues for expression (opportunity). Employee involvement can increase the AMO of employees, including decision-making, sharing of knowledge, horizontal communication and job enrichment (Appelbaum et al., 2000; Schimansky, 2014). Contrariwise, compensation and training yield an insignificant result with AMO model. As mentioned earlier, money in terms of salary as well as training provided cannot affect the employees' AMO. This result was opposed with the previous studies on ability and motivation enhancing practices such as training and compensation respectively. It was found that training and development practices help to increase the chances of new skills, understand the problem and identify new perspectives and also recruit and select people who fit the profile and the organisation (Bos-Nehles et al., 2013; Marin-garcia \& Tomas, 2016; Schimansky, 2014). On the compensation side, past studies had revealed that motivation-enhancing practices can ensure employees do the best to achieve their objectives and produced a high level of performance (Demortier et al., 2014; Munteanu, 2014).

Thirdly, the mediating role of AMO model between employee involvement with employee commitment has been established. This result was in line with Almutawa et al. (2016) that found the similar role of AMO model as having a partial mediation in the relationship between HR system and affective commitment. Employee involvement was identified as a full mediation effect, which means that by using the AMO model as a mediator in the research study, this factor has a significant positive relationship to employee commitment, which cannot be achieved through a direct relationship. This showed that employee involvement has no meaning without the ability, motivation and opportunity provided by the organisation. Employees will involve if they have the 
capacity to participate in the decision-making process, and have a proper knowledge of the job itself or the organisational issues. However, the AMO model does not mediate the relationship between compensation and training with employee commitment. As far as training is concerned, it showed that there was no mediation but it was categorised as non-mediation effects because the result indicated only the occurrence of a direct effect. This finding reflected that training had increased the ability, skills and knowledge of employees to do better in their daily work thus AMO was not needed to ensure the employee's commitment. Therefore, AMO does not have any impact on training, but still successfully leads to a higher level of commitment. SMEs should focus to provide more jobs related training so that employees can upgrade their skills especially in this Revolution 4.0 era. Compensation on the other hand, had no impact on mediation as well as on direct relationships. This indicates that something must be done and that SMEs should therefore consider revisiting their salary system and making it attractive to encourage employees and make them to stay.

This study offers timely and critical understanding into what drives Gen Y employees to commit and remain at a particular organisation. These findings may assist in understanding what pushes employees on a day-to-day level in the workplace and what drives their career in terms of overarching goals. The AMO model can be the dynamic key metric for organisations especially for owners, managers, and HR practitioners to create a positive impact on employee commitment. Finally, this study emphasises the findings that are related to the identified objectives, as well as research contribution to different parties. The results of this study signify a small portion in understanding the density of employee commitment as well as the AMO model approach; thus cannot be generalised. Future studies should adopt the proposed research model among different types of SMEs to generalise the findings and explore other relevant mediator or perhaps moderator by duplicating the method used by this present study. It is believed that such research would offer new, meaningful perspectives to the body of knowledge and give greater insights for the management as well as a practitioner in handling the seamless and sophisticated characteristic Gen Y employees, particularly in the SMEs.

\section{CONCLUSION}

The SMEs industry in Malaysia is captivated to capture both the domestic market and international opportunities. To achieve this vision, sufficient workforce and expertise both recently and in the future give the stability of the organisation. In order for SMEs to be more securing in terms of the workforce and the expertise of workers, they need to lessen the turnover of employees and have the best practice to gain the commitment of employees. As such, Gen Y employees are seeking for more involvement, opportunities and skills enhancing in order to commit themselves. SMEs should therefore learn something from this significant result in the preparation of appropriate training and to involve employees in the daily management activities that could make employees to stay. Additionally, the insignificant result also serves as an eye opener for SMEs to organize and respond to future organization planning to attract as well as retain employees. Therefore, this study responds to the commitment of employees among Gen Y employees by empirically testing existing HR practices such as compensation, training and employee involvement. Generally, it gives substantiation to the role of HR practices in developing a good workplace environment for organisation to gain employee commitment. On the other hand, it offers SMEs, the support for the needs of impactful human resource practices among employees to be combined in the field of talent 
management, which focuses on gaining the commitment of new generation employees in the organisation. The ultimate factor that could enhance employee commitment is the AMO model. With their presence in the organisation, and their combination with the effectiveness of HR practices, employees will remain longer, valued and satisfied. When the organisation provides employees with their needs and satisfies their expectations at work, they will feel appreciated and a factor called the reciprocity standard comes into play when they receive an appreciation for their work; they have a sense of commitment and a continuous high level of performance and a higher level of involvement and commitment, as per the SET (Saks, 2006).

\section{REFERENCES}

Abdullah, N. H., Wahab, E., \& Shamsuddin, A. (2010, December 5-7). Human Resource Management Practices as Predictors of Innovation among Johor SMEs. 2010 International Conference on Science and Social Research (CSSR) (pp. 878-883). Kuala Lumpur, Malaysia.

Adham, A. (2011). Employee Involvement and its Impact on Job Satisfaction and Organisational Commitment. International Journal of Sciences: Basic and Applied Research, 18(2), 368400 .

Almutawa, Z., Zhang, J., \& Muenjohn, N. (2016). The effect of human resource management system on employees ' commitment : The mediating role of the AMO model. The Journal of Developing Areas, 50(6), 17-29. https://doi.org/10.1353/jda.2016.0147

Amah, E., \& Ahiauzu, A. (2013). Employee involvement and organizational effectiveness. Journal of Management Development, 32(7), 661-674. https://doi.org/10.1108/JMD-09-2010-0064

Appelbaum, E., Bailey, T., Berg, P., \& Kalleberg, A. L. (2000). Manufacturing advantage: Why high-performance work systems pay off. London: ILR Press.

Aryee, S., Budhwar, P. S., \& Chen, Z. X. (2002). Trust as a mediator of the relationship between organizational justice and work outcomes: test of a social exchange model. Journal of Organizational Behavior, 23, 267-285. https://doi.org/10.1002/job.138

Bashir, N., \& Long, C. S. (2015). The relationship between training and organizational commitment among academicians in Malaysia. Journal of Management Development, 34(10), 1227-1245. https://doi.org/10.1108/JMD-01-2015-0008

Blau, P. M. (1964). Exchange \& Power in Social Life. New York: Wiley.

Bos-Nehles, A. C., Van, M. J., Riemsdijk, \& Looise, J. K. (2013). Employee perceptions of line management performance: Applying the AMO theory to explain the effectiveness of line managers' HRM implementation. Human Resource Management, 52(6), 861-877. https://doi.org/10.1002/hrm

Boxall, P., \& Purcell, J. (2011). Strategy and Human Resource Management $\left(3^{\text {rd }}\right.$ ed). England, UK: Palgrave Macmillan.

Brown, E. A., Thomas, N. J., \& Bosselman, R. H. (2015). Are They Leaving or Staying: A Qualitative Analysis of Turnover Issues for Generation Y Hospitality Employees with a Hospitality Education. International Journal of Hospitality Management, 46, 130-137.

Cardon, M. S., \& Stevens, C. E. (2004). Managing human resources in small organizations: What do we know? Human Resource Management Review, 14, 295-323. https://doi.org/10.1016/j.hrmr.2004.06.001

Chelliah, S., Sundarapandiyan, N., \& Vinoth, B. (2015). A Research on Employees' Organisational Commitment in Organisations: A Case of SMEs in Malaysia. International Journal of 
Managerial Studies and Research, 3(7), 10-18.

Chen, N. (2019). HRM Five: What employers need to know about millennials. https://hrmasia.com/author/natalie-chen/

Chibucos, T. R., Leite, R. W., \& Weis, D. L. (2004). Readings in Family Theory. USA: Sage Publications, Inc.

Coetzee, M., Mitonga-Monga, J., \& Swart, B. (2014). Human resource practices as Predictors of Engineering Staff 's Organisational Commitment. SA Journal of Human Resource Management, 12(1), 1-9. https://doi.org/10.4102/sajhrm.v12i1.604

Cohen, J. (1988). Statistical power analysis for the behavioral sciences (2 ${ }^{\text {nd }}$ ed). New York: Routledge.

Demortier, A.-L. P., Delobbe, N., \& Akremi, A. El. (2014). Opening the black box of HR practices - performance relationship: testing a three pathways AMO model. Academy of Management Annual Meeting Proceedings, 2014(1), 14932. https://doi.org/10.5465/ambpp.2014.102

DeNisi, A. S., \& Griffin, R. W. (2001). Human Resources Management. Houghton Mifflin Company, New York, NY.

Franke, G., \& Sarstedt, M. (2019). Heuristics versus statistics in discriminant validity testing: A comparison of four procedures. Internet Research, 29(3), 430-447. https://doi.org/10.1108/IntR-12-2017-0515

Gallie, D., Felstead, A., \& Green, F. (2001). Employer Ploicies and Organizational Commitment in Britain. Journal of Management Studies, 38(8), 1081-1101. https://doi.org/10.1111/14676486.00273

Ganesan, J., Mun, L. K., \& Raman, K. (2017). Determinants of Organisational Commitment Among Generation -Y in the Malaysian SMEs. Modern Applied Science, 11(12), 48-57. https://doi.org/10.5539/mas.v11n12p48

Geringer, J. M., Frayne, C. A., \& Milliman, J. F. (2002). In Search of "Best Practices" in International Human Resource Management: Research Design And Methodology. Human Resource Management, 41(1), 5-30. https://doi.org/10.1002/hrm.10017

Guay, F., Vallerand, R. J., \& Blanchard, C. (2000). On the Assessment of Situational Intrinsic and Extrinsic Motivation: The Situational Motivation Scale (SIMS). Motivation and Emotion, 24(3), 175-213.

Guest, D. E. (1997). Human resource management and performance: a review and research agenda. The International Journal of Human Resource Management, 8(3), 263-376.

Guest, D. E. (2011). Human resource management and performance: still searching for some answers. Human Resource Management, 21(1), 3-13. https://doi.org/10.1111/j.17488583.2010.00164.x

Guest, D. E., Michie, J., Sheehan, M., \& Conway, N. (2000). Employment Relations, HRM and Business Performance: An Analysis of the 1998 Workplace Employee Relations Survey. London: IPD.

Hair, J. F., Ringle, C. M., \& Sarstedt, M. (2011). PLS-SEM : Indeed a Silver Bullet. Journal of Marketing Theory and Practice, 19(2), 139-152. https://doi.org/10.2753/MTP10696679190202

Hair, J. F., Black, W. C., Babin, B. J., \& Anderson, R. E. (2013). Multivariate Data Analysis. New York: Pearson Education Limited.

Hair, J. F., Hult, G. T. M., Ringle, C. M., \& Sarstedt, M. (2017). A Premier On Partial Least Squares Structural Equation Modeling (PLS-SEM). Thousand Oaks, CA: Sage Publications, Inc.

Hair, J. F, Sarstedt, M., Ringle, C. M., \& Gudergan, S. P. (2018). Advanced Issues in Partial Least 
Squares Structural Equation Modeling. Thousand Oaks, CA: Sage Publications, Inc.

Hashim, J. (2010). Human Resource Management Practices on Organisational Commitment: The Islamic Perspective. Personnel Review, 39(6). https://doi.org/10.1108/00483481011075611

Hashim, J., Ismail, Y., \& Hassan A. (2016). Formality of HRM Practices Matters to Employees Satisfaction and Commitment. Journal of Human Resources Management and Labor Studies, 4(1), 47-64. https://doi.org/10.15640/jhrmls.v4n1a2

Hassan, S., \& Mahmood, B. (2016). Relationship between HRM Practices and Organizational Commitment of Employees : An Empirical Study of Textile Sector in Pakistan. International Journal of Academic Research in Accounting, Finance and Management Sciences, 6(1), 2328. https://doi.org/10.6007/IJARAFMS/v6-i1/1952

Henseler, Jörg, Ringle, C. M., \& Sarstedt, M. (2015). A new criterion for assessing discriminant validity in variance-based structural equation modeling. Journal of the Academy of Marketing Science, 43, 115-135. https://doi.org/10.1007/s11747-014-0403-8

Henseler, Jorg, Ringle, C. M., \& Sinkovics, R. R. (2009). The Use of Partial Least Squares Path Modeling in International Marketing. Advances in International Marketing, 20, 277-319. https://doi.org/10.1108/S1474-7979(2009)0000020014

Herold, D. M., \& Fedor, D. B. (2003). Individual differences in feedback propensities and training performance. Human Resource Management Review, 13, 675-689. https://doi.org/10.1016/j.hrmr.2003.11.008

Hooi, L. W., \& Ngui, K. S. (2014). Enhancing organizational performance of Malaysian SMEs The role of HRM and organizational learning capability. International Journal of Manpower, 35(7), 973-995. https://doi.org/10.1108/IJM-04-2012-0059

Ihionkhan, P. A., \& Aigbomian, E. E. (2014). The Influence of Human Resource Management Practices on Organisational Commitment: A Study of Manufacturing Organisations in Nigeria. Indian Journal of Commerce \& Management Studies, 5(1), 18-28.

Johar, E. R., Nor, N. M., Hassan, R., \& Musa, R. (2019). Examining the Effect of Motivation on the Influence of Human Resource Practices and Normative Commitment Among SMEs In Selangor. Asia-Pacific Management Accounting Journal, 14(1), 179-200.

Jones, D. C., Kalmi, P., \& Kauhanen, A. (2010). How Does Employee Involvement Stack Up? The Effects of Human Resource Management Policies on Performance in a Retail Firm. Industrial Relations, 49(1), 1-22.

Kline, R. B. (2016). Principles and Practice of Structural Equation Modeling. New York: Guilford Press.

Kock, N., \& Lynn, G. S. (2012). Lateral Collinearity and Misleading Results in Variance-Based SEM : An Illustration and Recommendations Lateral Collinearity and Misleading Results in Variance-. Journal of the Association for Information, 13(7), 546-580.

Latorre, F., Guest, D., Ramos, J., \& Gracia, F. J. (2016). High commitment HR practices , the employment relationship and job performance: A test of a mediation model. European Management Journal, 34(4), 328-337. https://doi.org/10.1016/j.emj.2016.05.005

Lee, C.-C., \& Chen, C.-J. (2013). The Relationship between Employee Commitment and Job Attitude and Its Effect on Service Quality in the Tourism Industry. American Journal of Industrial and Business Management, 3, 196-208.

Lin, S., Lin, J. S., \& Lin, Y. (2012). Human resource management practices affecting organizational commitment: A study on CEO's transformational leadership. African Journal of Business Management, 6(22), 6575-6586. https://doi.org/10.5897/AJBM12.041

Ling, L., Qing, T., \& Shen, P. (2014). Can training promote employee organizational commitment? The effect of employability and expectation value. Nankai Business Review International, 
5(2), 162-186. https://doi.org/10.1108/NBRI-09-2013-0034

Lyons, P. (2009). Action theory and the training and performance application: performance templates. Industrial and Commercial Training, 41(5), 270-279. https://doi.org/10.1108/00197850910974811

Mabaso, C. M., \& Dlamini, B. I. (2018). Total rewards and its effects on organisational commitment in higher education institutions. SA Journal of Human Resource Management, 16, 1-8. https://doi.org/10.4102/sajhrm.v16i0.913

Mahal, P. K. (2012). HR Practices as Determinants of Organizational Commitment and Employee Retention. The IUP Journal of Management Research, 11(4), 37-53.

Marin-garcia, J. A., \& Tomas, J. M. (2016). Deconstructing AMO framework: A systematic review. Intagible Capital, 12(4), 1040-1087. https://doi.org/http://dx.doi.org/10.3926/ic.838

Merkle, D. M. (2008). Nonresponse Bias. In P. J. Lavrakas (Ed.), Encyclopedia of Survey Research Methods. Thousand Oaks, CA: Sage Publications, Inc.

Meyer, J. P., \& Allen, N. J. (1991). A three-component conceptualization of organizational commitment. Human Resource Management Review, 1(1), 61-89.

Mulolli, E., Islami, X., \& Skenderi, N. (2015). Human Resource Management Practices and SMEs Performance: Study Based In Kosovo. International Review of Management and Business Research, 4(4), 1171-1180.

Munteanu, A. (2014). What Means High Performance Work Practices for Human Resources in an Organization. Annals of the University of Petrosani, Economics, 14(1), 243-250.

National SME Development Council. (2012). SME Master Plan 2012-2020. National SME Development Council, Kuala Lumpur. http://www.smecorp.gov.my/index.php/en/resources /2015-12-21-11-07-06/sme-masterplan/book/11-sme-masterplan-english/3-sme-masterplan

National SME Development Council. (2017). SME Annual Report 2017/2018. National SME Development Council, Kuala Lumpur.

Noe, R. A., Hollenbeck, J. R., Gerhart, B., \& Wright, P. M. (2010). Human resource Management: Gaining a competitive Advantage. New York: McGraw-Hill/Irwin.

Nor, N. M., \& Abdullah, F. (2020). The Relationships between Ability, Motivation and Opportunity (AMO) Model of High-Performance Work Practices (HPWP) and Organizational Performance on Millennials in MARA Headquarters , Kuala Lumpur: Mediated by Job Embeddedness. International Journal of Academic Research in Business and Social Sciences, 10(13), 62-72. https://doi.org/10.6007/IJARBSS/v10-i13/6889

Osa, I. G., \& Amos, I. O. (2014). The Impact of Organizational Commitment On Employees Productivity: A Case Study of Nigeria Brewery, PLC. International Journal of Research in Business Management, 2(9), 107-122.

Podsakoff, P. M., MacKenzie, S. B., Lee, J. Y., \& Podsakoff, N. P. (2003). Common Method Biases in Behavioral Research: A Critical Review of the Literature and Recommended Remedies. Journal of Applied Psychology, 88(5), 879-903. https://doi.org/10.1037/00219010.88.5.879

Poole, M. (1997). Responsibilities for human resource management practices in the modern enterprise. Evidence from Britain. Personnel Review, 26(5), 333-356. https://doi.org/10.1108/00483489710176039

PricewaterhouseCoopers. (2011). Millennials at work Reshaping the workplace. https://www.pwc.com/co/es/publicaciones/assets/millennials-at-work.pdf

Queiri, A., Yusof, W. F. W., \& Dwaikatt, N. (2014). Generation-Y Employees’ Turnover: WorkValues Fit Perspective. International Journal of Business and Management, 9(11), 199-213. https://doi.org/10.5539/ijbm.v9n11p199 
Randstad. (2019). Malaysia 2019. Employer Brand Research. https://www.mdbc.com.my/wpcontent/uploads/2019/08/Randstad-Malaysia-2019-Employer-Brand-Research.pdf

Rizzo, J. R., House, R. J., \& Lirtzman, S. I. (1970). Role Conflict and Ambiguity in Complex Organizations. Administrative Science Quarterly, 15(2), 150-163.

Saks, A. M. (2006). Antecedents and Consequences of Employee Engagement. Journal of Managerial Psychology, 21(7), 600-619. https://doi.org/10.1108/02683940610690169

Saunders, M. N. K., Thornhill, A., \& Lewis, P. (2009). Research Methods for Business Students ( $5^{\text {th }}$ ed). UK: Harlow, Essex : Pearson Education.

Schimansky, S. (2014). The Effect of a High-Commitment Work System on Innovative Behavior of Employees [Unpublished bachelor's thesis]. University of Twente.

Schyns, B., \& Collani, G. Von. (2002). A new occupational self-efficacy scale and its relation to personality constructs and organizational variables. European Journal of Work and Organizational Psychology, 11(2), 219-241. https://doi.org/10.1080/13594320244000148

Shin, D., \& Konrad, A. M. (2014). Causality Between High-Performance Work Systems and Organizational Performance. Journal of Management, 43(4), 973-997. https://doi.org/10.1177/0149206314544746

SME Corporation Malaysia. (2017). Annual Report 2017. https://www.smecorp.gov.my/images/SMEAR/SMEAR2017/ENG/FULL.pdf

Tabiu, A., Pangil, F., \& Othman, S. Z. (2016). HRM Practices and Employee Performance: The Mediation Effect of Ability, Motivation and Opportunity. Asian Journal of Multidisciplinary Studies, 4(6), 130-136.

Vandenberg, R. J., Richardson, H. A., \& Eastman, L. J. (1999). The Impact Of High Involvement Work Processes on Organizational Effectiveness. Group \& Organization Management, 24(3), 300-339. https://doi.org/10.1177/1059601199243004

Voorhees, C. M., Brady, M. K., Calantone, R., Ramirez, E., \& Brady, M. K. (2016). Discriminant validity testing in marketing: an analysis, causes for concern, and proposed remedies. Journal of the Academy of Marketing Science, 44(1), 119-134. https://doi.org/10.1007/s11747-015-0455-4

Wayne, S. J., Shore, L. M., Bommer, W. H., \& Tetrick, L. E. (2002). The Role of Fair Treatment and Rewards in Perceptions of Organizational Support and Leader - Member Exchange. Journal of Applied Psychology, 87(3), 590-598. https://doi.org/10.1037//00219010.87.3.590

Wayne, S., Shore, L. M., \& Liden, R. C. (1997). Perceived Organizational Support and LeaderMember Exchange : A Social Exchange Perspective. The Academy of Management Journal, 40(1), 82-111. https://doi.org/10.2307/257021

Whitener, E. M. (2001). Do "high commitment" human resource practices affect employee commitment? A cross-level analysis using hierarchical linear modeling. Journal of Management, 27, 515-535. https://doi.org/10.1016/S0149-2063(01)00106-4

Williams, B. (1978). A Sampler on Sampling. New York, NY: John Wiley \& Sons.

Yu, J., \& Cooper, H. (1983). A Quantitative Review of Research Design Effects on Response Rates to Questionnaires. Journal of Marketing Research, 20(1), 36-44.

Zakaria, N., Mohamed Zainal, S. R., \& Nasurdin, A. M. (2011). Investigating The Role of Human Resource Management Practices On The Performance of SME: A Conceptual Framework. Journal of Global Management, 3(1), 80-98.

Zopiatis, A., Constanti, P., \& Theocharous, A. L. (2014). Job involvement, commitment, satisfaction and turnover: Evidence from hotel employees in Cyprus. Tourism Management, 41, 129-140. https://doi.org/10.1016/j.tourman.2013.09.013 